\title{
A novel chelating resin with diphenyl disulphide functional group: Synthesis, sorption, separation and recovery of some heavy metal ions
}

\author{
Preeti R. Dwivedi* and J.K.Verma \\ Inorganic Research Laboratory, K.J.Somaiya college of Science and Commerce, Vidyanagar, Vidyavihar, \\ MUMBAI-400077, India
}

\begin{abstract}
A novel chelating resin containing diphenyl disulphide as a functional group, supported on poly(ethylacrylate-acrylonitrile-divinylbenzene) was synthesized by suspension polymerization and characterized by elemental analysis, physico-chemical properties thermal studies, FTIR studies and scanning electron microscopy. With the help of batch equilibrium technique, the selectivity and binding capacities of chelating resin were measured towards certain metal ions in different electrolyte concentration, wide $p H$ range and different time intervals. The maximum adsorption capacities of the resin for $\mathrm{Co}(\mathrm{II}), \quad \mathrm{Ni}(\mathrm{II}), \mathrm{Cu}(\mathrm{II}), \mathrm{Zn}(\mathrm{II})$, $\mathrm{Cd}$ (II), $\mathrm{Hg}$ (II) and $\mathrm{Pb}$ (II) were evaluated to be 24.27, 24.59, 24.02, 24.52, 23.94, 22.46 and $19.26 \mathrm{mg} \mathrm{g}^{-1}$ respectively at $\mathrm{pH} 7,10,11,6,8,3.5$ and 5 respectively. With the help of chromatographic separations, the recoveries of $\mathrm{Zn}(\mathrm{II})$ and $\mathrm{Cd}(\mathrm{II})$ were found to be $99.05 \%$ and $98.68 \%$ respectively from their binary mixture. In case of ternary mixture of $\mathrm{Zn}(\mathrm{II}), \mathrm{Cd}(\mathrm{II})$ and $\mathrm{Hg}$ (II) the recoveries as obtained were $98.10 \%, 98.02 \%$ and 97.9\% respectively. The synthesized resin was also used to recover $\mathrm{Zn}(\mathrm{II}), \quad \mathrm{Cd}(\mathrm{II})$ and $\mathrm{Ni}$ (II) from industrial wastewater samples each containing a single metal ion, and $\mathrm{Cu}$ (II) and $\mathrm{Ni}$ (II) from Printed Circuit Board $(P C B)$ scrap.
\end{abstract}

Keywords: Chelating ion-exchange resin, sorption studies, column chromatography and elution.

\section{Introduction}

It is well known that various dissolved toxic metal ions, species or compounds in industrial wastewaters and natural waters pose severe environmental and health problems to ecological systems as well as human life [1]. Toxic heavy metals such as lead $(\mathrm{Pb})$, mercury $(\mathrm{Hg})$, cadmium $(\mathrm{Cd})$, nickel $(\mathrm{Ni})$, etc. tend to accumulate and concentrate in the environments leading to severe health problems [2]. Several methods have been widely applied for removal, extraction, separation and pre-concentration of heavy metal ions from wastewaters as well as other environmental samples [3].

Chelating resins are designed for selective adsorption, separation and pre-concentration of metal ions and usually employed in wastewater treatment, in the recovery and removal of metal ions and in accurate analysis of heavy metal ions $[4,5]$.

Chelating resins are polymers with covalently bound functional groups containing one or more donor atoms which are capable of forming complexes directly with metal ions and can also be used in the separation of metal ions from solutions. Since sulphur containing groups are soft bases, resins with sulphur containing functional group are useful for the removal of soft acids like $\mathrm{Cu}, \mathrm{Pb}, \mathrm{Cd}$, etc. [6].

Chelating resins containing bis-(2aminophenyl) disulphide [7], dithiocarbamate sporopollenin derivative [8], mixture of sulphadiazine and trimethylolphenol [9], thiosemicarbazide [10], and chitosan-phenyl thiourea [11] have been used to investigate the adsorption properties and also applied for selective separation of specific metal ions.

The present paper deals with the synthesis and characterization of a novel chelating resin containing diphenyl disulphide derived from poly(ethyl acrylate-acrylonitrile-divinyl benzene) and highly cross-linked polystyrene. This resin has been studied for its sorption behaviour towards heavy metal ions viz., Co (II), Ni (II), Cu (II), Zn (II), $\mathrm{Cd}$ (II), $\quad \mathrm{Hg}$ (II) and $\mathrm{Pb}$ (II) and in the separation of heavy metal ions from binary and ternary mixtures, industrial wastewater and printed circuit board (PCB) scrap solution.

\section{Experimental}

\subsection{Chemicals}

Diphenyl disulphide (DPDS), ethyl acrylate, styrene, acrylonitrile and divinylbenzene used were from Aldrich-Sigma. All the metal salts were procured from Merck and Loba Chemie Company. Double distilled water was used throughout the work.

\subsection{Preparation of DPDS resin}

DPDS micro beads were prepared by a suspension polymerization process by placing 250 $\mathrm{mL}$ distilled water, $8 \mathrm{~mL}$ of $2 \%$ gelatine solution, 
$2.0 \mathrm{~g}$ calcium carbonate, $12 \mathrm{~g}$ anhydrous sodium sulphate and toluene in a three necked round bottom flask fitted with a condenser, a mechanical stirrer and a thermometer. With stirring $3 \mathrm{~mL}$ styrene, $8.5 \mathrm{~mL}$ ethyl acrylate, $38 \mathrm{~mL}$ acrylonitrile and $0.5 \mathrm{~g}$ benzoyl peroxide (initiator) were added. The reaction temperature was maintained at $85^{\circ} \mathrm{C}$. After 6 hours, beads were filtered off using a Buchner funnel, washed successively with hot water, methanol and $1 \mathrm{M} \mathrm{HCl}$ and dried under vacuum for 72 hours.

The resin beads were then converted into beads containing hydroxyl group according to literature [12]. The product thus obtained was refluxed with $6 \mathrm{~g}$ of diphenyl disulphide containing $6 \mathrm{~mL}$ of $18 \mathrm{M} \mathrm{H}_{2} \mathrm{SO}_{4}$ as a catalyst for 52 hours at $85-90^{\circ} \mathrm{C}$ in a round bottom flask with continuous stirring using a magnetic stirrer. The beads were filtered and washed first with hot methanol and then with distilled water and dried in vacuum for 36 hours. The synthesis of the resin beads is represented schematically in Fig. 1.

\section{Fig.1: Schematic synthesis of DPDS-resin}

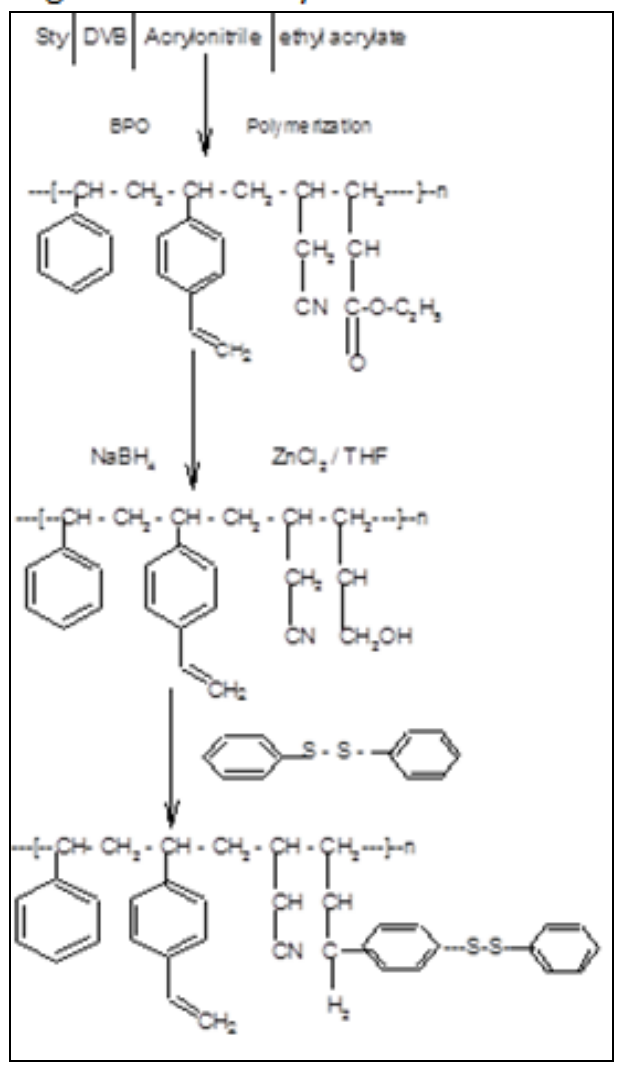

\subsection{Uptake measurements by Batch methods 2.3.1 Preparation of solutions}

All metal ion solutions used in the experimental studies were prepared in double distilled water. A stock solution of EDTA $(0.02 \mathrm{M})$ was prepared and standardized against a solution of $\mathrm{MgSO}_{4} .7 \mathrm{H}_{2} \mathrm{O}$ using Erichrome Black $\mathrm{T}$ as an indicator. The $\mathrm{pH}$ of metal ion solution was adjusted by using a buffer of acetic acid and ammonia ( $\mathrm{pH} 2.5-12)$.

\subsubsection{Sorption Experiments}

By batch method, under controlled $\mathrm{pH}$, the sorption equilibrium was attained by shaking $0.5 \mathrm{~g}$ of dry resin in $25 \mathrm{~mL}$ of aqueous metal ion solution. After 24 hours solution was filtered and leached with $30 \mathrm{~mL}$ of $2 \mathrm{~N} \mathrm{HCl}$. The metal ion concentration of the leached solution was measured by complexometric titrations with standard EDTA solution.

The rate of loading of metal ions on the resin was determined by shaking $0.5 \mathrm{~g}$ of dry resin with $25 \mathrm{~mL}$ of metal ion solution at optimum $\mathrm{pH}$ for different time intervals. The solution was filtered and the sorbed metal ions were completely eluted by $30 \mathrm{~mL}$ of $2 \mathrm{~N} \mathrm{HCl}$. The metal ion concentration was measured by complexometric titrations with standard EDTA solution.

To determine the metal ion uptake in the presence of electrolyte of different concentrations, $0.25 \mathrm{~g}$ of dry resin was suspended in an electrolyte (25mL) viz., $\mathrm{NaCl}, \mathrm{KCl}, \mathrm{NaNO}_{3}$ and $\mathrm{Na}_{2} \mathrm{SO}_{4}$ of known concentrations viz., $0.01 \mathrm{M}, 0.1 \mathrm{M}$ and 0.5 $\mathrm{M}$ at optimum $\mathrm{pH}$. After equilibrating for 24 hours, $2 \mathrm{~mL}$ of $0.1 \mathrm{M}$ metal ion solution was added and again equilibrating for 24 hours. The metal ion content was determined by complexometric titration against standard EDTA solution. The amount of metal ion taken up by the polymer in the presence of given electrolyte then could be calculated from the difference between the actual titration value and that of the blank.

\subsection{Column Separations}

A glass column of $25 \mathrm{~cm}$ length and $1 \mathrm{~cm}$ internal diameter was packed with the slurry of $\mathrm{H}^{+}$ form of resin $(1 \mathrm{~g})$. The column was equilibrated at required $\mathrm{pH}$ using $0.2 \mathrm{M}$ acetate buffer.

Separations of binary mixture of $\mathrm{Cd}$ (II) and $\mathrm{Zn}$ (II) and ternary mixture of $\mathrm{Zn}$ (II), Cd (II) and $\mathrm{Hg}$ (II) were attempted at optimised conditions.

\section{4a Recovery of Heavy Metal Ions ( $\mathrm{Zn}, \mathrm{Cd}$ and Ni) from Industrial Wastewater samples}

With the help of ion-exchange resin, metal ions viz., Zn (II), Cd (II) and Ni (II) from industrial wastewater can be easily removed. Prior to use, all the resin was converted in the sodium form, as per the procedure cited in literature [13]. Three different glass columns of length $25 \mathrm{~cm}$ and $1 \mathrm{~cm}$ internal diameter were packed with $1.0 \mathrm{~g}$ of those resin and equilibrated with about $25 \mathrm{~mL}$ of $0.2 \mathrm{M}$ acetate buffer. Then $5 \mathrm{~mL}$ of the industrial wastewater samples containing each of the ions viz., Zn (II), Cd (II) and Ni (II) were introduced in to individual columns separately. After eluting the metal ion sorbed on the resin with respective 
eluting agents, the concentration of each metal ion in eluent were determined by complexometric titrations.

\section{4b Recovery of Copper and Nickel from Printed Circuit Board (PCB) scrap}

Leach liquor from Printed Circuit Board scrap was prepared according to literature [14]. $10 \mathrm{~mL}$ of leach solution was passed into a column (25 $\mathrm{cm}$ length, $1 \mathrm{~cm}$ id) containing $1 \mathrm{~g}$ of sodium form of resin. $7 \mathrm{M} \mathrm{H}_{2} \mathrm{SO}_{4}$ and $0.25 \mathrm{M}$ tartaric acid as an eluting agent for copper and nickel respectively were passed through the column at a flow rate of $0.5 \mathrm{~cm}^{3} / \mathrm{min}$. The recovery of copper and nickel metal ion in eluent was determined by complexometric titration method.

\section{Results and Discussions}

The chelating resin was synthesized from 36-44 mesh sized beads of ethyl acrylateacrylonitrile-divinylbenzene copolymer through the steps shown in Fig.1. The results of elemental analysis showed the presence of $10.1 \%$ sulphur as reported in Table 1.

\begin{tabular}{|c|c|c|c|}
\hline \multicolumn{5}{|c|}{ Analysis Calculated (\%) Found (\%) } \\
\hline$C$ & $H$ & $N$ & 5 \\
\hline $\begin{array}{c}79.2 \\
(78.09)\end{array}$ & $\begin{array}{c}6.42 \\
(6.27)\end{array}$ & $\begin{array}{c}2.5 \\
(2.41)\end{array}$ & $\begin{array}{c}11.74 \\
(10.1)\end{array}$ \\
\hline
\end{tabular}

Table1. Elemental Analysls ofDPDS-resin

Based on analytical data the empirical formula of the repeating unit was found to be $\mathrm{C}_{36} \mathrm{H}_{35} \mathrm{NS}_{2}$. The physicochemical parameters of the synthesized resin were evaluated and are presented in Table 2.

\begin{tabular}{|c|c|}
\hline Properties & Values \\
\hline Moisture (\%) & 1.3047 \\
\hline Solid (\%) & 98.70 \\
\hline $\begin{array}{l}\text { True density (dry resin) } \\
\mathrm{g} / \mathrm{cm}^{3}\end{array}$ ) & 0.589 \\
\hline $\begin{array}{l}\text { Apparent density (dry resin) } \\
\mathrm{g} / \mathrm{cm}^{3}\end{array}$ & 0.7096 \\
\hline Void volume $(\%)$ & $16.99 \%$ \\
\hline $\begin{array}{l}\text { Hydrogen ion capacity } \\
\text { (meq/g dry resin) }\end{array}$ & 0.62 \\
\hline $\begin{array}{l}\text { Sodium exchange capacity } \\
\text { (meq/g dry resin) }\end{array}$ & 1.2 \\
\hline
\end{tabular}

Table 1: Physicochemical parameters of DPDS-resin

The linkages and the functional groups present in the resin were confirmed through FTIR analysis (Fig. 2). The appearances of a band at $2931.39 \mathrm{~cm}^{-1}, 2868.88 \mathrm{~cm}^{-1}$ and $1406.38 \mathrm{~cm}^{-1}$ showed the presence of $(\mathrm{C}-\mathrm{H})$ stretching vibrations, $-\mathrm{CH}_{2}$ - symmetrical stretching vibrations and vinyl group respectively. A sharp band at $1185.69 \mathrm{~cm}^{-1}$, a weak band at $676.18 \mathrm{~cm}^{-1}$ and a band at $491.33 \mathrm{~cm}^{-}$ ${ }^{1}$ indicate the presence of thiocarbonyl group, C-S group and S-S stretching group respectively.

The thermograph of DPDS resin, shown in Fig.3, reveals that the sample undergoes degradation in one step. A maximum weight loss equivalent to $48.605 \%$ took place in the temperature range from $325^{\circ} \mathrm{C}$ to $400^{\circ} \mathrm{C}$ with constant heating rate of $10^{\circ} \mathrm{C}$ per minute in nitrogen atmosphere.

The morphology of the synthesized resin was investigated by scanning electron microscopy, where white bar at the bottom represents the scale (Figs. 4 and 5).

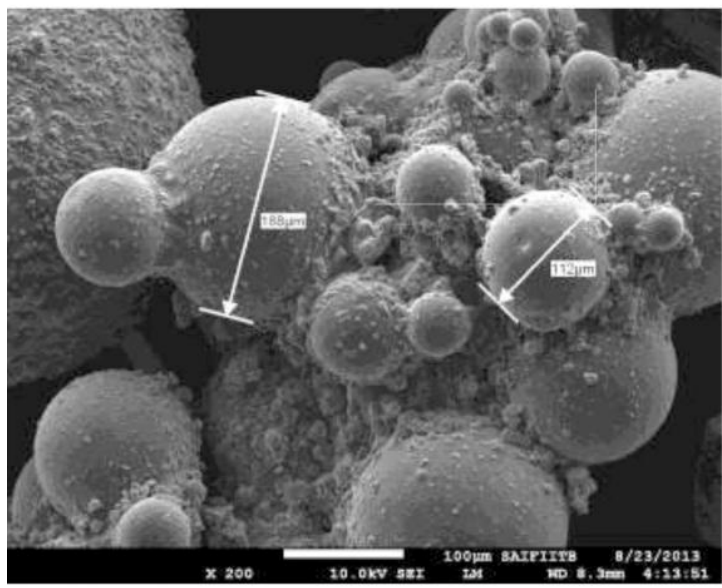

Fig.4: SEM of DPDS-resin

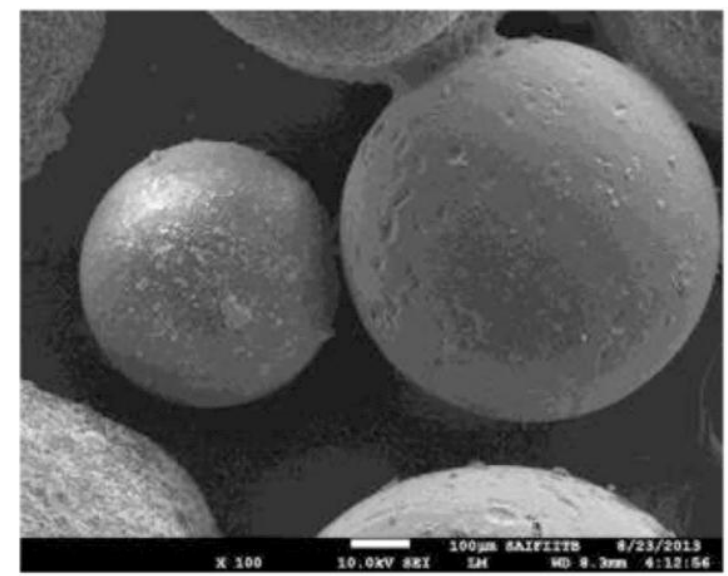

Fig. 5: SEM of DPDS-resin

\subsection{Effect of pH on metal ion uptake}

The sorption of various metal ions viz., Co (II), Ni (II), Cu (II), Zn (II), Cd (II), $\mathrm{Hg}$ (II) and $\mathrm{Pb}$ (II) on chelating resin at various $\mathrm{pH}$ values was investigated and the results are shown in Fig.6. The metal ion uptake was found to be dependent on $\mathrm{pH}$ 


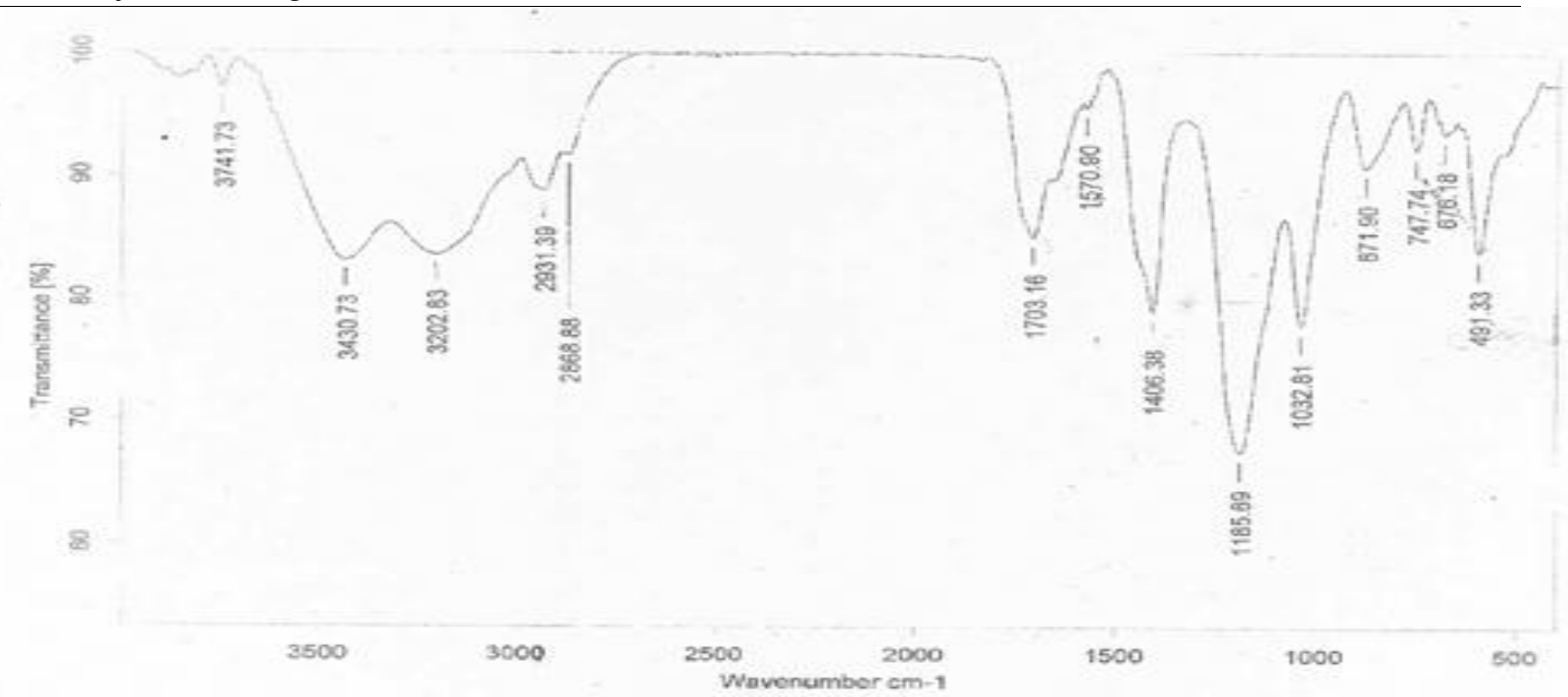

Fig.2: FTIR of DPDS-resin

of the medium. For each metal ion, there is an optimum $\mathrm{pH}$ at which maximum intake of metal ion takes place. The maximum ion-exchange capacity for $\mathrm{Co}$ (II), $\mathrm{Ni}$ (II), Cu (II), Zn (II), Cd (II), $\mathrm{Hg}$ (II) and $\mathrm{Pb}$ (II) is observed at a $\mathrm{pH} 7,10,11,6$, $8,3.5$ and 5 respectively. The order of distribution ratio of the metal ions is:

\section{$\mathrm{Cu}$ (II) $>\mathrm{Pb}$ (II) $=\mathrm{Co}$ (II) $>\mathrm{Zn}$ (II) $>\mathrm{Ni}$ (II) $>\mathrm{Cd}$ (II) $>\mathrm{Hg}$ (II) $(98 \%)(96 \%)(96 \%)(89 \%)(79 \%) \quad(69 \%) \quad(66 \%)$}

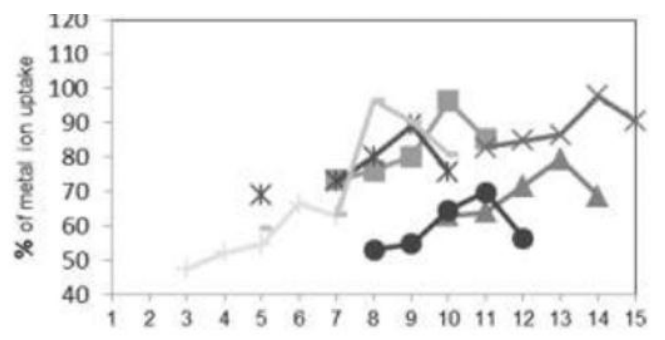

$\mathrm{pH}$ for maximum adsorption of metal ions as evaluated in Table 3.

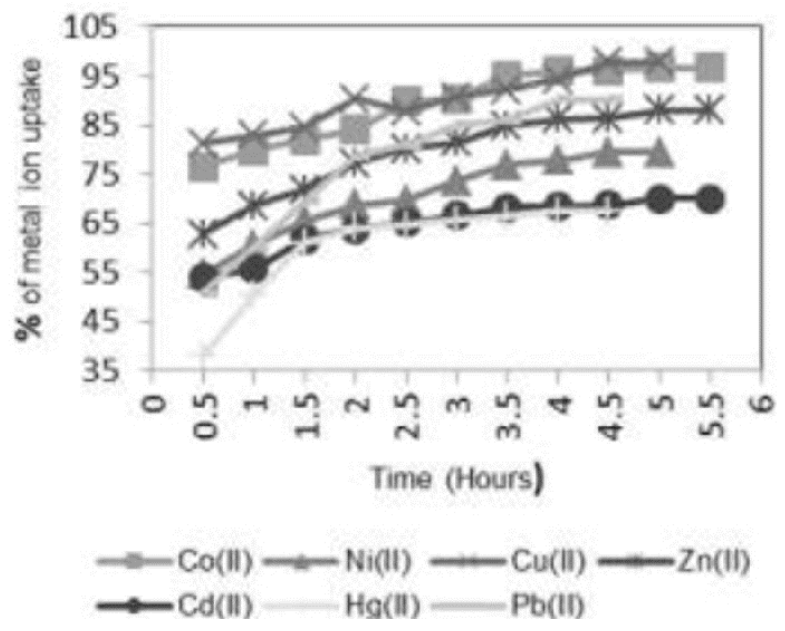

Fig.7: Effect of time on metal ion uptake
$=\mathrm{Co}(\mathrm{II}) \leadsto \mathrm{Ni}(\mathrm{II}) \longrightarrow \mathrm{Cu}(\mathrm{II}) \longrightarrow \mathrm{Zn}(\mathrm{II}) \leadsto \mathrm{Cd}(\mathrm{II}) \longrightarrow \mathrm{Hg}(\mathrm{II})$

Fig.6: Effect of $\mathrm{pH}$ on metal ion uptake

\subsection{Effect of time on metal ion uptake}

Fig.7 shows adsorption rates of heavy metal ions by the synthesized resin as a function of time. To determine the rate of loading of seven metal ions viz., Co (II), $\mathrm{Ni}$ (II), $\mathrm{Cu}$ (II), Zn (II), Cd (II), $\mathrm{Hg}$ (II) and $\mathrm{Pb}$ (II) on the resin, batch experiments were carried out at optimum $\mathrm{pH}$. The time required (ii) Among seven metal ions taken for study $\mathrm{Pb}$ (II) and $\mathrm{Hg}$ (II) required shortest time i.e., about 4 hours, whereas, $\mathrm{Cu}$ (II) and $\mathrm{Ni}$ (II) require 4.5 hours and Co (II), Cd (II) and $\mathrm{Zn}$ (II) required longest time i.e. about 5 hours to reach the equilibrium. Thus, the rate of metal ion uptake for the synthesized resin follows the order:

$\mathrm{Pb}(\mathrm{II})=\mathrm{Hg}(\mathrm{II})<\mathrm{Cu}(\mathrm{II})=\mathrm{Ni}(\mathrm{II})<\mathrm{Co}(\mathrm{II})=\mathrm{Cd}$ $($ II) $=\mathrm{Zn}(\mathrm{II})$ 
IOSR Journal of Applied Chemistry (IOSR-JAC)

e-ISSN: 2278-5736. Volume 7, Issue 1 Ver. II. (Feb. 2014), PP 57-63

www.iosrjournals.org

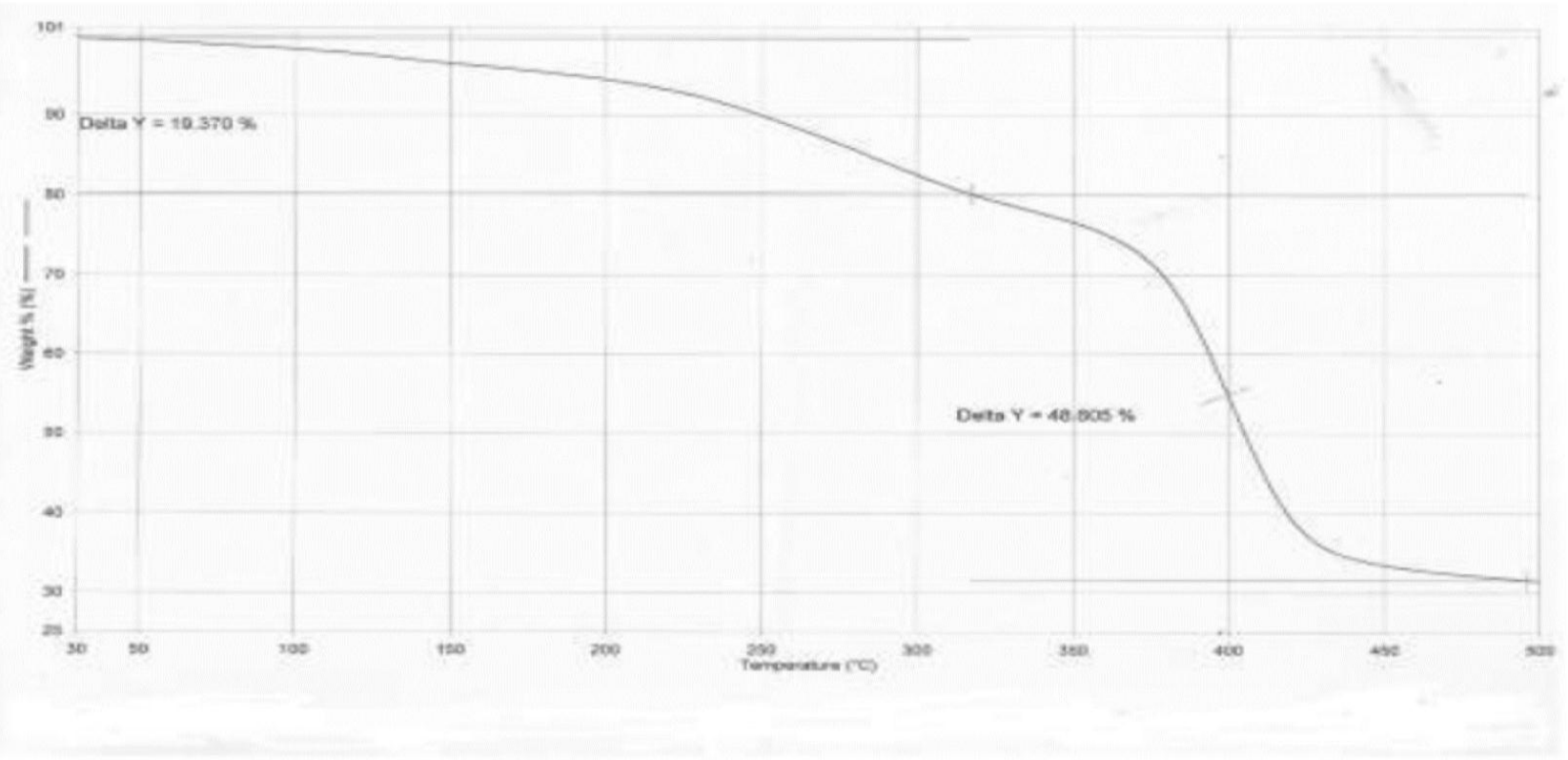

Fig. 3: TGA of DPDS-resin

\subsection{Study of the Effect of Different Electrolytes on Metal ion Uptake}

The data obtained for resin with different electrolytes with various concentrations (Table 4) reveals that the amount of metal ion taken for a given amount of resin sample depends on the nature and concentration of electrolyte present in the solution. In presence of chloride ions, the amount of $\mathrm{Co}$ (II), $\mathrm{Ni}$ (II), $\mathrm{Cu}$ (II), Zn (II), Cd (II), $\mathrm{Hg}$ (II) and $\mathrm{Pb}$ (II) increases with increasing concentration of electrolyte, while in presence of nitrate and sulphate ions, the amount of the same metal ions decreases with increasing concentration. (Fig.8-11).The order of uptake of metal ions by the resin in presence of electrolyte at different concentration follows the order:

$\mathrm{Pb}$ (II) $>\mathrm{Hg}$ (II) $>\mathrm{Cd}$ (II) $>\mathrm{Zn}$ (II) $>\mathrm{Cu}$ (II) $>\mathrm{Ni}$ (II) $>\mathrm{Co}$ (II)

\begin{tabular}{|c|c|c|c|c|c|c|c|}
\hline Metal ions & $\begin{array}{c}\mathrm{Cu} \\
\text { (II) }\end{array}$ & $\begin{array}{c}\mathrm{Co} \\
\text { (II) }\end{array}$ & $\begin{array}{c}\mathrm{Pb} \\
\text { (II) }\end{array}$ & $\begin{array}{c}\mathrm{Zn} \\
\text { (II) }\end{array}$ & $\begin{array}{c}\mathrm{Ni} \\
\text { (II) }\end{array}$ & $\begin{array}{c}\text { Cd } \\
\text { (II) }\end{array}$ & $\begin{array}{c}\mathrm{Hg} \\
\text { (II) }\end{array}$ \\
\hline Time(hours) & 4.5 & 5 & 4 & 5 & 4.5 & 5 & 4 \\
& & & & & & & \\
\hline
\end{tabular}

Table 3: Time required by the for maximum adsorption

4.5 Chromatographic Separations

4.5.1 Separation of Binary Mixture of $\mathrm{Zn}$ (II) and $\mathrm{Cd}$ (II)

For the separation of binary mixture of $\mathrm{Zn}$ (II) and $\mathrm{Cd}$ (II), $10 \mathrm{~mL}$ of 1:1 mixture of $\mathrm{Zn}$ (II) and Cd (II) were passed through the column at $\mathrm{pH} 6$ using $0.2 \mathrm{M}$ acetate buffer at a flow rate of $0.5 \mathrm{~cm}^{3} \mathrm{~min}^{-1}$. Separation was achieved with the help of selective elution technique by first passing $150 \mathrm{~mL}$ of 0.5

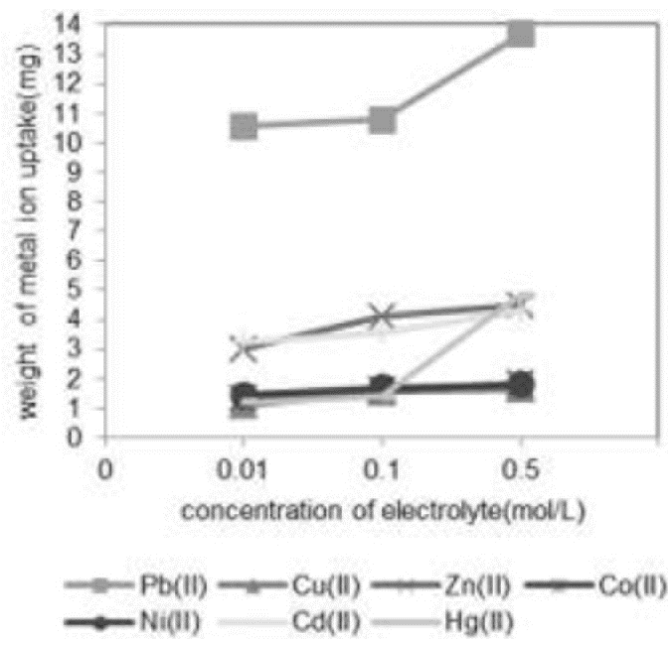

Fig.8: Effect of $\mathrm{KCl}$ on metal ion uptake

$\mathrm{MHCl}$ as an eluent for zinc followed by $150 \mathrm{~mL}$ of $1 \mathrm{M} \mathrm{HNO}_{3}$ for elution of cadmium. Recovery of $\mathrm{Zn}$ (II) and Cd (II) were found to be $99.05 \%$ and $98.68 \%$ respectively.

\section{(b) Separation of $\mathrm{Hg}$ (II), Cd (II) and Zn (II)}

In the separation of ternary mixture of $\mathrm{Zn}$ (II), Cd (II) and $\mathrm{Hg}$ (II), $10 \mathrm{~mL}$ of 1:1:1 mixtures of $\mathrm{Hg}$ (II), Cd (II) and $\mathrm{Zn}$ (II) were passed through the column at $\mathrm{pH} 3.5$ using $0.2 \mathrm{M}$ acetate buffer at a flow rate of $0.5 \mathrm{~cm}^{3} \mathrm{~min}^{-1}$. The mercury was eluted with $150 \mathrm{~mL}$ of $5 \%$ thiourea in $1 \mathrm{M} \mathrm{HClO}_{4}$. The zinc (II) was further eluted with $150 \mathrm{~mL}$ of $0.5 \mathrm{M}$ $\mathrm{HCl}$ and cadmium (II) was eluted with $150 \mathrm{~mL}$ of 1 $\mathrm{M} \mathrm{HNO}_{3}$. The recoveries of $\mathrm{Zn}$ (II), Cd (II) and $\mathrm{Hg}$ (II) were found to be $98.10 \%, 98.02 \%$ and $97.8 \%$ respectively. 

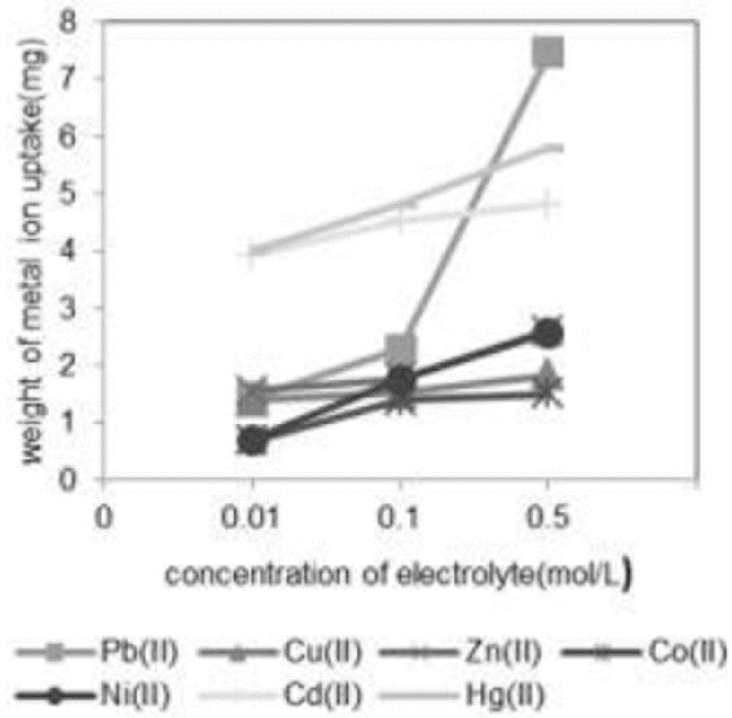

Fig.9: Effect of $\mathrm{NaCl}$ on metal ion uptake
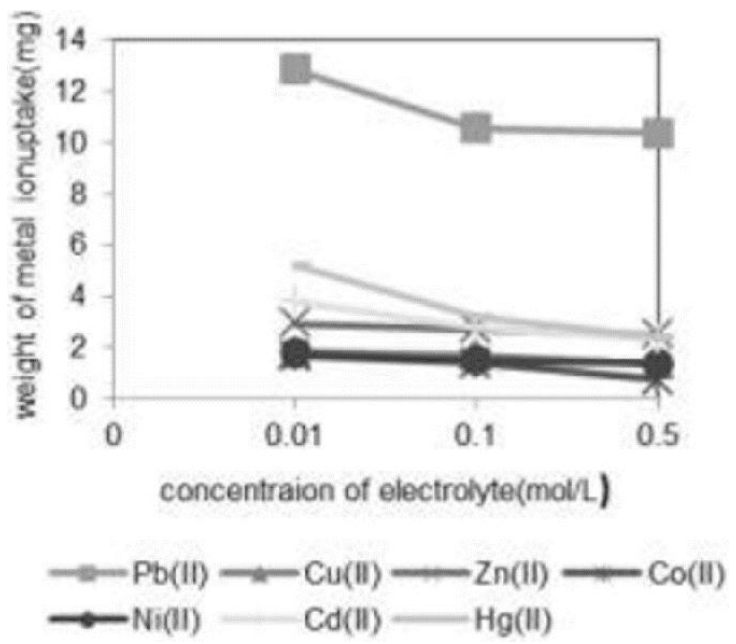

Fig.10: Effect of $\mathrm{NaNO}_{3}$ on metal ion uptake

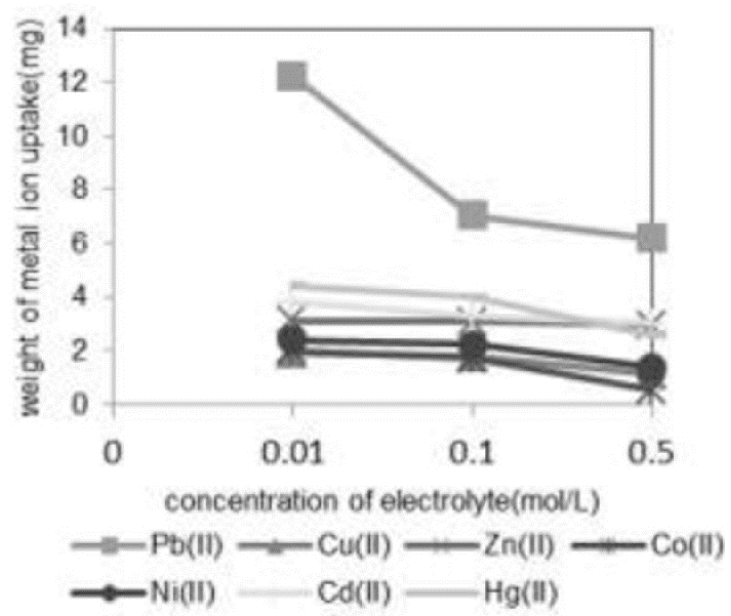

Fig.11: Effect of $\mathrm{Na}_{2} \mathrm{SO}_{4}$ on metal ion uptake

\subsubsection{Recovery of $\mathrm{Zn}, \mathrm{Cd}$ and $\mathrm{Ni}$ from Industrial Wastewater}

With the help of column chromatography the recovery of $\mathrm{Zn}$ (II), Cd (II) and Ni (II) from industrial wastewater was carried out individually. $\mathrm{Zn}$ (II), Cd (II) and Ni (II) were eluted with $0.5 \mathrm{M} \mathrm{HCl}, 1 \mathrm{M} \mathrm{HNO}_{3}$ and $0.25 \mathrm{M}$ tartaric acid respectively at a flow rate of $0.5 \mathrm{~cm}^{3} / \mathrm{min}$. Recoveries of zinc, cadmium and nickel were found to be $97.83 \%, 99.35 \%$ and $97.55 \%$ respectively.

\subsubsection{Recovery of Copper and Nickel from Printed Circuit Board (PCB) scraps}

The resin beads were successfully employed for the recovery of copper (98.21\%) and for nickel $(96.90 \%)$ from a leach solution prepared from PCB scrap.

\section{Conclusions}

A novel chelating resin containing diphenyl disulphide synthesized from poly(ethylacrylate-acrylonitrile-divinylbenzene) beads was characterized by elemental analysis and physicochemical properties. The presence of functional group and linkages required for the resin structure was confirmed by FTIR analysis. TGA revealed the one step degradation of the resin showing good thermal stability for the resin. The order of distribution ratio of the metal ions studied was found to be: $\mathrm{Cu}$ (II) $>\mathrm{Pb}$ (II) $=\mathrm{Co}$ (II) $>\mathrm{Zn}$ (II) $>\mathrm{Ni}$ (II) > Cd (II) > Hg (II). It has been demonstrated that the chromatographic separation of binary mixture viz., $\mathrm{Zn}$ (II) and $\mathrm{Cd}$ (II) and ternary mixtures of $\mathrm{Zn}$ (II), Cd (II) and $\mathrm{Hg}$ (II) can be done successfully as per the procedures developed. Furthermore, Zn (II), Cd (II) and Ni (II) from industrial wastewater samples were recovered using the resin. Finally, $\mathrm{Cu}$ (II) and Ni (II) from PCB scrap were also be separated using the resin effectively.

\section{Acknowledgements}

The authors are thankful to the SAIF, IIT Bombay for providing the instrumental facilities pertaining to FTIR, SEM, TGA and Elemental Analysis. We are also thankful to Mr. Sandeep Maru, Manager of Jalaram Metal Finishers Company for providing samples of industrial wastewater for the present work. 
IOSR Journal of Applied Chemistry (IOSR-JAC)

e-ISSN: 2278-5736. Volume 7, Issue 1 Ver. II. (Feb. 2014), PP 57-63

www.iosrjournals.org

\begin{tabular}{|c|c|c|c|c|c|}
\hline \multirow{2}{*}{ Metal ions } & \multirow{2}{*}{$\begin{array}{c}\text { Concentration } \\
\text { of electrolytes } \\
\text { (mol/L) }\end{array}$} & \multicolumn{4}{|c|}{ Weight of metal ion uptake in presence of electrolytes } \\
\hline & & $\mathrm{KCl}$ & $\mathrm{NaCl}$ & $\mathrm{NaNO}_{3}$ & $\mathrm{Na}_{2} \mathrm{SO}_{4}$ \\
\hline $\mathrm{Pb}^{+2}$ & $\begin{array}{c}0.01 \\
0.1 \\
0.5\end{array}$ & $\begin{array}{l}10.56 \\
10.77 \\
13.67\end{array}$ & $\begin{array}{l}1.45 \\
2.28 \\
7.46\end{array}$ & $\begin{array}{l}12.84 \\
10.56 \\
10.36\end{array}$ & $\begin{array}{c}12.22 \\
7.04 \\
6.19\end{array}$ \\
\hline $\mathrm{Cu}^{+2}$ & $\begin{array}{c}0.01 \\
0.1 \\
0.5\end{array}$ & $\begin{array}{l}1.08 \\
1.55 \\
1.65\end{array}$ & $\begin{array}{l}1.39 \\
1.52 \\
1.84\end{array}$ & $\begin{array}{l}1.84 \\
1.73 \\
1.38\end{array}$ & $\begin{array}{l}1.90 \\
1.78 \\
1.14\end{array}$ \\
\hline $\mathrm{Zn}^{+2}$ & $\begin{array}{c}0.01 \\
0.1 \\
0.5\end{array}$ & $\begin{array}{c}3.0 \\
4.09 \\
4.49\end{array}$ & $\begin{array}{l}1.56 \\
1.77 \\
2.61\end{array}$ & $\begin{array}{l}2.94 \\
2.74 \\
2.53\end{array}$ & $\begin{array}{l}3.13 \\
3.07 \\
2.94\end{array}$ \\
\hline $\mathrm{Co}^{+2}$ & $\begin{array}{c}0.01 \\
0.1 \\
0.5\end{array}$ & $\begin{array}{l}1.32 \\
1.59 \\
1.83\end{array}$ & $\begin{array}{l}0.69 \\
1.39 \\
1.51\end{array}$ & $\begin{array}{l}1.69 \\
1.41 \\
0.76\end{array}$ & $\begin{array}{c}2.0 \\
1.70 \\
0.53\end{array}$ \\
\hline $\mathrm{Ni}^{+2}$ & $\begin{array}{c}0.01 \\
0.1 \\
0.5\end{array}$ & $\begin{array}{l}1.46 \\
1.70 \\
1.81\end{array}$ & $\begin{array}{l}0.70 \\
1.76 \\
2.58\end{array}$ & $\begin{array}{l}1.81 \\
1.51 \\
1.40\end{array}$ & $\begin{array}{l}2.40 \\
2.23 \\
1.40\end{array}$ \\
\hline $\mathrm{Cd}^{+2}$ & $\begin{array}{c}0.01 \\
0.1 \\
0.5\end{array}$ & $\begin{array}{l}3.23 \\
3.59 \\
4.29\end{array}$ & $\begin{array}{l}.93 \\
4.53 \\
4.82\end{array}$ & $\begin{array}{l}3.82 \\
2.81 \\
2.35\end{array}$ & $\begin{array}{l}3.81 \\
3.28 \\
3.02\end{array}$ \\
\hline $\mathrm{Hg}^{+2}$ & $\begin{array}{c}0.01 \\
0.1 \\
0.5\end{array}$ & $\begin{array}{l}1.20 \\
1.40 \\
4.81\end{array}$ & $\begin{array}{l}4.01 \\
4.81 \\
5.81\end{array}$ & $\begin{array}{l}5.22 \\
3.21 \\
2.41\end{array}$ & $\begin{array}{l}4.41 \\
4.01 \\
2.61\end{array}$ \\
\hline
\end{tabular}

Table 3: Evaluation of the effect of different electrolytes on the uptake of several metal ions of HTG resin

$\mathrm{M}^{+2}\left(\mathrm{NO}_{3}\right)_{2}: 0.1 \mathrm{M}$; volume: $2 \mathrm{~mL}$; volume of electrolyte: $25 \mathrm{~mL}$; weight of resin: $25 \mathrm{mg}$; time $24 \mathrm{~h}$; temperature:25-30 ${ }^{\circ} \mathrm{C}$

\section{References}

[1] A.B. Perez-Marin, V.M. Zapata, J.F. Ortuno, M. Aguilar, J. Saez, M. Llorens, J of Hazardous Material, 139 (2007) 122-131.

[2] D.Mohan, K.P. Singh, Water Res., 36 (2002) 23042318.

[3] M. E. Mahmoud, M M. Osman, O F. Hafez, A H. Hegazi, E. Elmelegy, Desalination, 25 (2010)123130.

[4] A. Saglam, S. Bektas, S. Patir, O.Gence, A. Denizli, React Funct Polym, 47 (2001) 185-192.

[5] T.P. Rao, P. Metilda, J.M. Gladis, Talanta, 68 (2006) 1047-1052.

[6] G. Kantipuly, S. Katragadda, A. Chow, H.D. Gessar, Talanta, 37 (1990) 491-499.

[7] B.C. Mondal, A.K. Das, Indian J. Chem Sec A, 41A (2002) 1821.
[8] U. Nuri, E. Mustafa, Separation and Purification Technology, 52 (2007) 461-469.

[9] S. Mojtaba, J. Mehran, G. Ghasemi, R.G. Mohammad, L. Vito, G. Alessandra, Separation and Purification Technology, 28 (2002) 141-147.

[10] A. Mohamed, A. Riswan, J.K. Duraisamy, A.R. Barkanudeen, J..Hazardous Materials, 248-249 (2013) 59-68.

[11] M.Monier, D.A. Latif, J. Hazardous Materials, 209210 (2012) 240-249.

[12] I. H. Park, K.M. Kim, Separation science and technology, 40 (2005) 2963-2986.

[13] Koivula R, Lehto J, Pajo L, Gale T and Leinone H, Hydrometallurgy, 56 (2000) 93-108.

[14] Sridhar, V.; Verma, J.K.; Kumar, S.A., (2011). Selective adsorption of copper and nickel by solvent extraction using LIX 984N. Hydrometallurgy, $99,124-126$. 